\title{
Towards a new way of measuring service delivery in Gauteng: Calculating a Fortunate Index
}

\author{
Peter Schmitz ${ }^{1,2}$, Sanet Eksteen ${ }^{1,3}$, and Stefan de Bruin ${ }^{l}$ \\ ${ }^{1}$ Centre for Geoinformation Science, University of Pretoria \\ ${ }^{2}$ CSIR \\ ${ }^{3}$ Esri South Africa
}

\section{DOI: http://dx.doi.org/10.4314/sajg.v4i3.12}

\begin{abstract}
We live in a society where government organisations must provide some of the needs of communities. If the needs of a community are not met, they may feel unhappy and negative towards government organisations. Such feelings may motivate a society towards criminal tendencies. If government organisations can measure how fortunate a community is in terms of goods and services delivered to them they can manage and apply their financial resources to benefit the community.

The purpose of this study is to develop a methodology for measuring how fortunate a community is in terms of what they perceive as important against what they receive from government. The perceptions of what respondents consider important were determined based on a list of predefined goods and services. The best methodology to calculate a fortunate index (FI) was identified and evaluated using various statistical methods. The FI for the Census 2001 data was then compared with that of the Census 2011 data to determine if government had improved on their service delivery. This research focuses on the methodology of developing a FI, and thus only a limited sample size was used to establish what people perceive as being fortunate. To our knowledge a similar methodology has not been developed for South Africa. The FI proposes a new innovative way to determine if government provides the needs of a community.
\end{abstract}

Keywords: fortunate index, census, community, happiness

\section{Introduction}

What does it mean to be 'fortunate'? A fortunate person is described as a person who has all the material comforts that he/she needs (YourDictionary, 2013). The Oxford English Dictionary (Simpson and Weiner, 1989) describes fortunate as: "Favoured by fortune; possessed of or receiving good fortune; lucky; prosperous. Said of persons; also of an enterprise, event, etc." In a society where people have needs that must be met by government, a feeling arises as to whether the needs are met or not. Since emotion is the driving force of all human behaviour, this may become an issue of concern if a society feels that their needs are not met. Not only does this result in a group of unhappy people that are negative towards the local and national government, but it may also motivate a society towards criminal tendencies (Flango et al, 2006). Booysen (2014) compiled a database of 123 incidents of protest action against poor service delivery by the government in South Africa between the $1^{\text {st }}$ of November 2013 and the $7^{\text {th }}$ of May 2014 (the day of the South African national and provincial elections). Criminality during the protest ranged from burning municipal offices and councilors' houses, looting, assaults and acts of intimidation (Booysen, 2014). This tendency towards crime or social unrest is in a sense self-defeating since crime and social unrest are contributing factors to unhappiness as well as being unfortunate (Borrero, et al, 2013). This may lead to a cycle of being unfortunate and not being able to turn it around to being fortunate since service providers may feel unsafe to provide the services required.

The term "fortunate" in the context of this paper is used to distinguish it from "happiness" as referred to in the literature since happiness is derived from emotion experienced whereas fortunate refers to the state in which a person finds him/herself in. 'Being fortunate' is thus defined as the state where items or services that are valued most by a specific individual are indeed owned by or served to that specific individual. In other words, if a person values post grade 12 education much higher than running water in the dwelling and that person has no post grade 12 education, but an abundance of running water in the dwelling, the person would be classified as being unfortunate (de Bruin, 2013). This raises the question whether one can measure how 'fortunate' a community is in terms of services delivered by the government and if one can measure if government improve on service delivery to contribute towards the 'fortunateness' of a community. In a world where money and political power are the main driving forces of government action (Clark \& D'Angelo, 2009), one could rightfully ask why anyone would be concerned with the emotions of citizens? A rather logical link between happiness and the well-being of a specific area is the issue of people not being motivated to continue living in places where they feel unfortunate. This will ultimately lead to the younger, more innovative generation moving away from a specific area to one where they feel more satisfied with life (Clark \& D'Angelo, 2009). The knowledge of unfortunate areas does assist government to allocate their financial resources better and improve service delivery in lagging areas. In South Africa most of the service delivery protests as compiled by Booysen (2014) did occur in the township areas created by the previous dispensation under Apartheid.

The aim of this paper is to establish a methodology to determine if a set of indicators can be used to calculate a fortunate index for the population of Gauteng in order to indicate if government is improving on service delivery. 
Figure 1 shows the location of Gauteng province in South Africa. The first objective of this study is to establish, based on a list of predefined services and goods, what people desire in order to be considered fortunate.

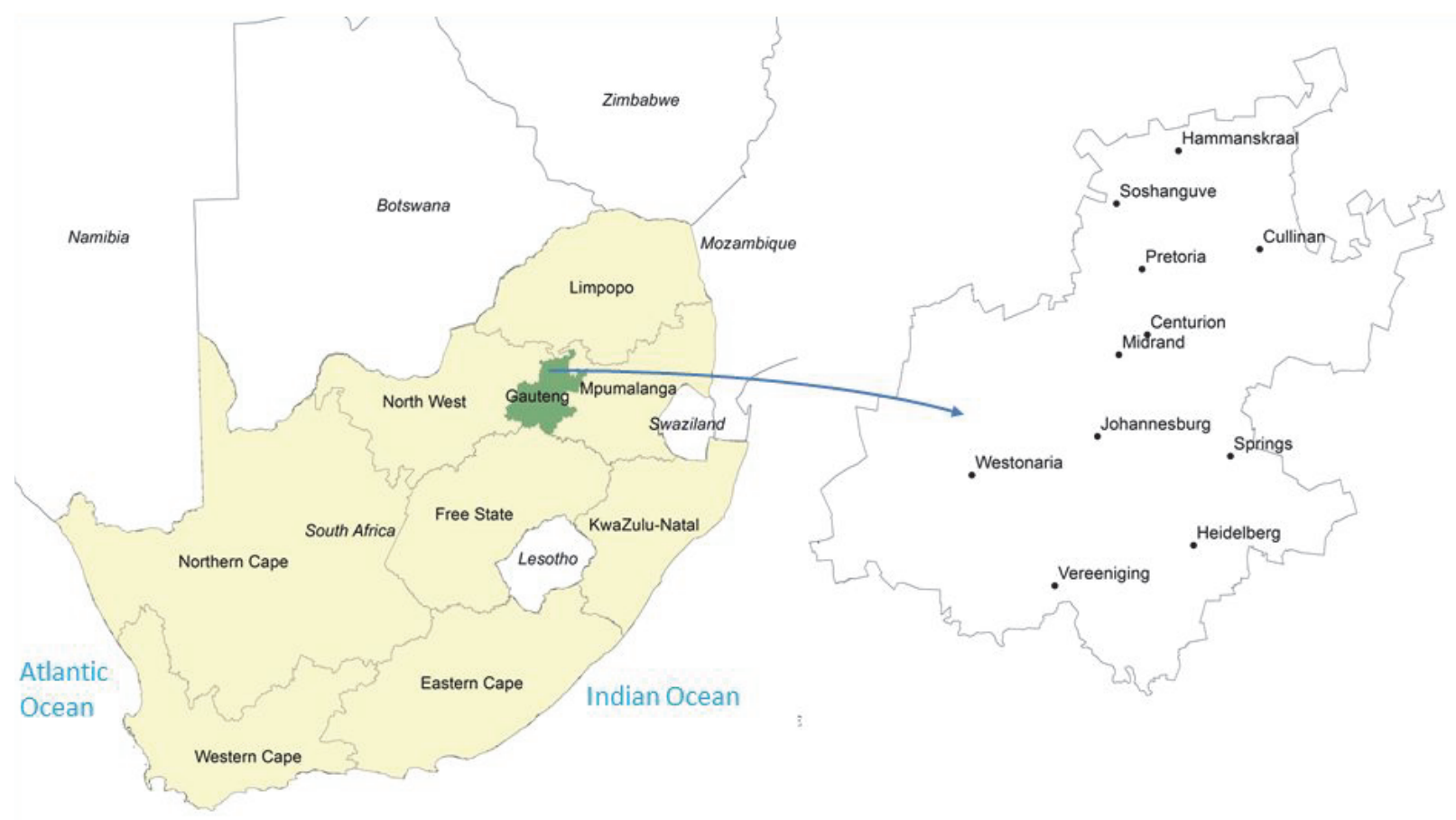

Figure 1. Location of Gauteng province

The second objective is to find the best methodology to derive a FI that can be used as an indicator of being fortunate. Various statistical methods are then applied to test the validity of the proposed method to calculate a FI. The FI is then calculated using data from Census 2001 and 2011 to determine if government meets the needs of the community. The indices are then compared to determine if government has improved on service delivery. The result will indicate if government is providing the needs of the population of Gauteng. Since this research focuses on the methodology of developing a FI index a limited sample size of the population was used to establish what people see as being fortunate. This sample selection method is known as purposive sampling (Tongco, 2007). The index is calculated for the Gauteng Province in South Africa. To our knowledge a similar methodology has not been developed for South Africa.

The remainder of this article is structured as follows: in Section 2 we discuss the Gross National Happiness in Bhutan followed by related studies that have been done in other countries. Section 4 explains the methodology used to derive the FI and in Section 5 we discuss the findings of this study. In Section 6 we conclude and propose recommendations on how to calculate a FI for South Africa.

\section{Literature review}

Although many indices are calculated as indicated by McGillivray (1991), Easterlin (1995), Hicks (1997), BarreraRoldan and Saldivar-Valdes (2002), Erasmus (2004), Rojas (2007), Kugaso (2008) and QoL (2011) to list a few, the idea for this study is based on the Happiness Index in Bhutan as this index measures an emotional well-being rather than an economic well-being. The first initiative with regard to measuring 'being happy' was done by a small Buddhist country called Bhutan. Bhutan is located on the Asian continent bordered by India in the south and China in the north. They regard happiness as a greater asset to their country than money. While other countries place emphasis on wealth, Bhutan's goal is, instead, happiness. In Bhutan gross national happiness (GNH) is valued more than gross national product (GNP) (Heeks, 2009). In order to enable the citizens to see the benefits of GNH the citizens are educated in the principles of GNH. The citizens are therefore aware that their life satisfaction is being measured for the use of decision making that will contribute towards their happiness (CBS, 2005).

The GNH index is calculated by taking nine domains into account (Ura et al, 2012). These domains are summarised in Table 1. Each of the 9 domains comprises two to four indicators. The nine domains each carry an equal weight while the indicators are weighted. An individual achieves complete happiness if a score of at least $66 \%$ is obtained in all the weighted indicators of the 9 domains. The happiness cut off value is thus $66 \%$ (CBS, 2012). It is therefore possible to be considered completely happy if $100 \%$ is scored for any 6 domains and $0 \%$ for the other 3 . An individual does not need to score $100 \%$ in all 9 domains to be considered happy, because not all indicators are relevant to each individual. People living in a city may have a different perception of happiness than people living in the countryside. 
Table 1. Domains used to calculate GNH in Bhutan (Ura et al, 2012)

\begin{tabular}{l}
\hline Domain \\
\hline Psychological wellbeing \\
Health \\
Time use \\
Education \\
Cultural diversity and resilience \\
Good Governance \\
Community vitality \\
Ecological diversity and resilience \\
Living standards
\end{tabular}

This means that people with core achievements such as good health and efficient time use may be able to compensate internally for any other shortcomings. Consequently, a person without electricity or basic education may still be able to attain happiness (CBS, 2012).

Although similar studies were conducted in other countries they have not been developed to the same detailed application as in Bhutan.

In Japan a similar study has indicated that economic development should not just be seen as a function of financial assets but rather also as a function of life satisfaction (Kugaso, 2008). Another study by Easterlin (1995) and Rojas (2007) has indicated that there is no apparent correlation between an increase in income and an increase in happiness. This is mainly because of a person's ability to adapt to circumstances. If a person should experience higher income, the chances are very high that the person would quickly adapt and that it would have no noticeable effect on that person's happiness. This stationary state in happiness despite the increase in income is known as the Easterlin Paradox (Di Tella and MacCulloch, 2008). Di Tella and MacCulloch (2008) found that there is a positive correlation between happiness and income and the welfare state and to some extent life expectancy. However people get unhappy when comparing their average working hours, existing crime statistics, economic inflation and open trade with unemployment in their own countries and with similar statistics in other countries. Variables should be carefully selected when linking income with happiness, since income alone does not influence happiness (Di Tella and MacCulloch, 2008). Caporale, et al (2009) found the opposite, namely that there is a relationship between happiness and increased wealth using crosssectional studies rather than time series data as used by Easterlin. Alesina, et al (2004) also indicated that poor Europeans are more astute with regard to inequality and happiness than their American counterparts. Borrero, et al (2013) looked at the relationship between wealth and happiness from two perspectives, namely individualism and collectivism, and found that poorer people under collectivism are happier than their individualist counterparts. Brereton, Clinch and Ferreira (2008) expanded the research into wealth and happiness to include the proximity of amenities, public transport, climate, pollution, landfills and major roads to name a few factors. The authors found that that people living too close to major roads and landfills decreases happiness while close proximity to the coast increases happiness. (Brereton, Clinch and Ferreira, 2008).

In South Africa, the Quality of Life survey was conducted during 2011 by the Gauteng City Regional Observatory (GCRO). This survey mainly focused on the life satisfaction of Gauteng citizens. This was established by asking questions to respondents concerning satisfaction with regard to specific aspects, such as dwelling, water, sanitation, waste removal, energy resources, security and standard of living. This study revealed some interesting trends. It has been indicated that more than $81 \%$ of Gauteng citizens are satisfied or very satisfied with water services provided to them. On the other hand it is noticeable that a third of Gauteng citizens are dissatisfied or very dissatisfied with the safety and security provided to them by the government (QoL, 2011). Knowing where there are specific areas where the needs of a community are not met, may help the local municipalities to draw up a better budget and provide the real needs of the community (Booysen, 2014).

Another study conducted by the City of Tshwane focused on a development index. This index identified the least ideal wards and most perfect wards in terms of infrastructure development and poverty eradication in the City of Tshwane. In order to compile the development index a service provision index and a social vulnerability index was developed. In addition, the study leads to the development of a human poverty index and a human development index on ward level. (Erasmus, 2004) 
The above indices were all developed using extensive surveys and/or through the development of indices without determining what is valued by the communities. This research investigated the development of an index using existing data without conducting extensive surveys.

\section{Methodology}

For the purpose of this study, eleven items were considered as indicators for the calculation of the FI. These items are measureable goods and services that are directly or indirectly provided by the government to communities. These items were chosen because they were captured by Statistics South Africa (StatsSA) as part of the Census 2001 and 2011 surveys (StatsSA, 2001; StatsSA, 2014). The chosen items can be used to compare the respondent's perceptions of what they consider as being fortunate vs. what services and goods the government directly or indirectly provides according to the Census 2001 and 2011 data. The indicators included in this study were obtained per sub-place and are summarised in Table 2. A sub-place consists of an aggregated group of enumerator areas as defined by StatsSA. Sub-places were used to calculate the FI as census data per enumerator area is not available to the general public (StatsSA, 2001).

Table 2. Variables included in calculating the FI

\begin{tabular}{l}
\hline Indicators \\
\hline Being employed \\
A degree/diploma/certificate from a tertiary institution \\
A permanent house that you own yourself \\
Flush toilet \\
Telephone/cell phone in the house \\
Three or more bedrooms in the house \\
Refuse removal once a week \\
Electricity for lighting \\
Electricity for heating \\
Electricity for cooking \\
Piped water in the dwelling
\end{tabular}

The next step was to establish the importance of these variables based on the perceptions of respondents. This was achieved by conducting a survey. The respondents had to rank the importance of the services and goods on a scale of 1 to 11 . The ranking made it possible to weigh these items up against each other. The results of the survey were then captured in a spreadsheet format to calculate the averages of the different rankings as indicated by the respondents. The average weights were then considered as an average rule of the importance of the services and goods to the respondents. For the purpose of this survey primary data was collected by interviewing the respondents. The respondents were selected using purposive sampling. Since this research focusses on the methodology of developing a FI index a limited sample size of the population was used to establish what people see as being fortunate.

The availability of goods and services per sub-place was then calculated. This was done by dividing the number of people who owned or were being served with a specific item by the entire population of the sub-place.

Since the Sabina-Alkire method (CBS, 2012) was used successfully to determine a Happiness index for Bhutan, an adaptation of this method was applied in determining the FI in Gauteng. In order to calculate the FI, the availability of the services and goods was multiplied by the average ranking of importance of the services and goods. The results were then summed to determine a final score for each sub-place. A maximum score of $66(1+2+3+4+5+6+7+8+9+10+11=$ 66) can be obtained for a sub-place if the government provides $100 \%$ in all services and goods to all the people in a subplace. As this is a highly unlikely situation, various cut-off values were introduced to calculate the fortunate index. The final summed score is then divided by the specified cut-off value to determine a fortunate index for each sub-place. The calculated fortunate index was then mapped using a geographical information system (GIS). The FI was classified into the following 5 categories based on natural breaks using Jenks' algorithm as provided in ArcGIS: completely fortunate, fortunate, content, unfortunate and completely unfortunate.

In the final step, various statistical methods were applied to test the validity of the fortunate index. By using the 2001 census data from StatsSA, it could be determined if there is a tendency for areas with high FI to correlate with areas with high monthly income and vice versa. An income of below R3200 per month per household was defined as low income. South Africa does not have an official poverty line (NPC, 2014). The income cut-off is based on the upper 
bound poverty line for 2011 as calculated by StatsSA (StatsSA, 2014). Dividing the number of all people with a monthly income of less than R3200 by the total population of the sub-place gives an indication of poverty. A false fortunate index (FFI) was then calculated to validate the FI. The FFI is the true average of the availabilities of the 11 items considered. The FFI does not take the assigned weights of the different items into account.

The resultant FIs for 2001 and 2011 were imported into a Geographical Information System (GIS). The FIs for the two years were then converted to a raster layer. A raster resolution of 50 meters was used. The size of the raster resolution was calculated based on the size of the smallest sub-place. The data sets were rasterized in order to compensate for the differences in sub-place boundaries between the two census years and for calculating the areas of change. In order to provide an indicator to government to establish improvement on service delivery the FI for 2001 was compared against the FI for 2011 to determine the change in the FI.

This study uses the census data from StatsSA to illustrate that an index can be constructed using existing data. This will enable organisations to focus their services to contribute towards what is needed by the societies and will minimize expenditure on extensive surveys. This study is limited in the way that only 11 items were used in the calculation of the FI. Although it is not comprehensive the methodology made it possible to compare the perception of what people considered as important with what is provided to them according to the Census data. This study focused on the development of a methodology and is therefore a qualitative study.

\section{Results and Discussion}

This section discusses the results and findings of this research.

\subsection{Establish the perception of being Fortunate}

The questionnaire survey was conducted in order to establish how the respondents prioritise goods and services provided to them. The results were used to establish general rules from which the FI can be calculated. The rules were established for all the respondents, then for males and females respectively and then for respondents younger and older than 35 years. The average age of the respondents was 35 years. The results used to establish 5 general rules are summarised in Table 3.

Table 3. General rule matrices

\begin{tabular}{llllcl}
\hline \multicolumn{1}{c}{ Item } & All & Male & Female & $<$ 35 years & $>=$ 35 years \\
\hline Employed & 9.773 & 10.692 & 8.444 & 10.000 & 9.583 \\
Degree/diploma & 6.500 & 6.000 & 7.222 & 7.100 & 6.000 \\
Permanent house & 10.318 & 10.154 & 10.556 & 10.200 & 10.417 \\
Toilet (flush) & 5.909 & 5.231 & 6.889 & 6.200 & 5.667 \\
Telephone/cell phone & 2.955 & 3.000 & 2.889 & 3.600 & 2.417 \\
Bedrooms > 3 & 5.091 & 5.769 & 4.111 & 5.200 & 5.000 \\
Refuse removal & 2.318 & 2.154 & 2.556 & 2.300 & 2.333 \\
Electricity for lighting & 6.455 & 5.846 & 7.333 & 6.100 & 6.750 \\
Electricity for heating & 3.227 & 3.385 & 3.000 & 2.900 & 3.500 \\
Electricity for cooking & 7.136 & 7.154 & 7.111 & 6.700 & 7.500 \\
Piped water in the dwelling & 6.318 & 6.615 & 5.889 & 5.700 & 6.833 \\
\hline
\end{tabular}

The general rules indicate that most people consider a permanent house as being the most important item followed by employment and access to electricity for cooking. Male respondents considered being employed as most important while female respondents considered having a permanent house as being the most important item. The age group above 35 years listed the items in the same order of importance as the general rule for all respondents while the age group below 35 listed having a degree or diploma as third most important. This may indicate that this age group understands the importance of education and that it may lead to a better quality of life. All the age and gender groups except the group younger than 35, listed electricity for heating, having a cell phone or telephone and refuse removal as the least important items. The group younger than 35 years considered having a cell phone or phone as being slightly more important than electricity for heating.

The validity of the proposed method was tested using the 2001 FI and 2001 census data. Once the FI was calculated for all sub-places in Gauteng, a comparison was made between the calculated FI of each sub-place and the availabilities 
South African Journal of Geomatics, Vol. 4, No. 3, August 2015

of each individual item. This was done to identify which of these items correlated the strongest or weakest to the FI. For all the items considered in this study, a positive correlation was expected, since the increase in the availability of an item will increase the FI

\subsection{Calculating the Fortunate Index}

As discussed before a score value of 66 is not realistic as this assumes that all the needs of the communities must be met. For the purpose of developing the methodology the cut-off score value was set to an arbitrary number of 53 to create a more realistic output and emphasises the less fortunate areas. A cut-off score value of 53 assumes that government will meet $80 \%$ of the needs of the community.

The calculation of the FI for 2001 indicated that $10 \%$ of all the sub-places in Gauteng are considered to be content while for 2011 the value decreased to 5\%, 22\% of the sub-places were fortunate in 2001 and 23\% in 2011. During 2001 $57 \%$ of the sub-places were completely fortunate compared to $64 \%$ in 2011 . If the classes are aggregated it indicates that during $200177 \%$ of the sub-places were fortunate because their needs were mostly met while $10 \%$ were content and $11 \%$ were unfortunate. The figures for 2011 increased to $87 \%$ as being fortunate, $5 \%$ content and $8 \%$ unfortunate. These results are summarised in Figure 2.

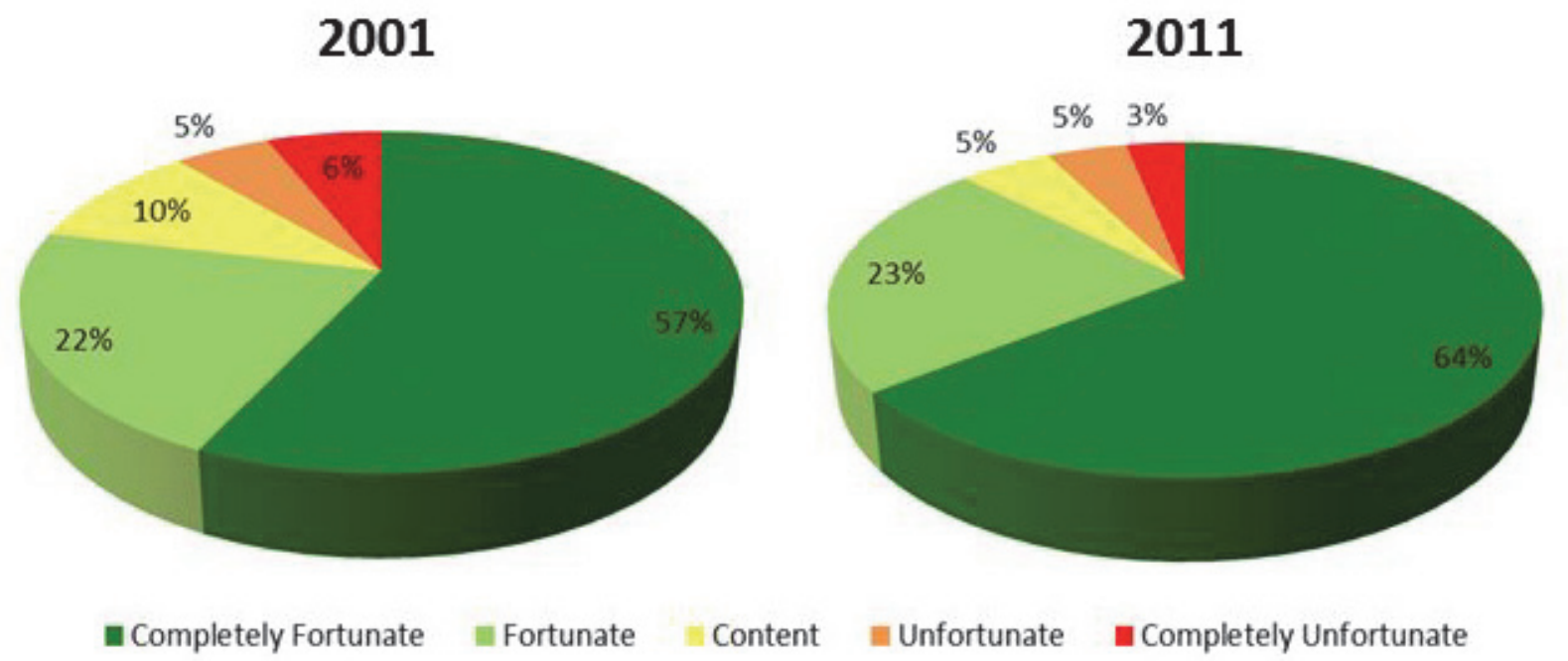

Figure 2. Level of Fortune for all Gauteng sub-places in 2001 and 2011

The calculated FIs for 2001 and 2011 are indicated in Figure 3. Sub-places that are considered to be more fortunate are located in and close to the central business districts of the City of Johannesburg and City of Tshwane. The rural areas and sub-places on the outskirts of the cities are less fortunate.

The areas indicated as completely unfortunate and unfortunate should be areas of highest concern as very few of the needs of the communities are met. 


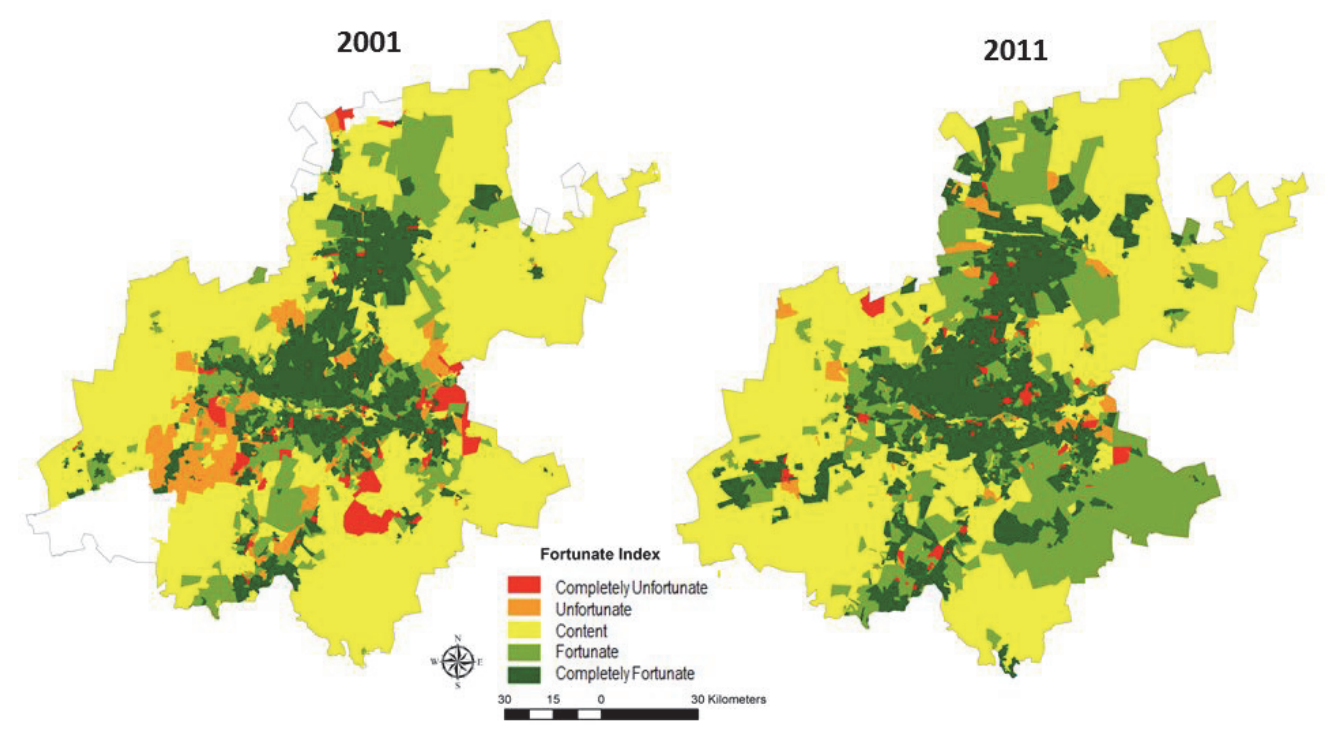

Figure 3. Fortunate Index for Gauteng (cut-off 53)

The comparison of the FI for 2001 and 2011 is summarised in Figure 4 and Table 4. The comparison indicates that government has improved on services in $6 \%$ of the areas, $2 \%$ from unfortunate to fortunate and $4 \%$ from unfortunate to content and $18 \%$ changed from content to fortunate. Twenty four percent of the areas remained fortunate in 2001 and 2011 , while $38 \%$ remained content and $1 \%$ remained unfortunate.

Almost $4 \%$ of the area deteriorated from fortunate to content and $0.5 \%$ from deteriorated from fortunate to unfortunate. By applying this methodology government will be able to spend resources on services that are perceived as being important by the community. In addition they will be able to identify areas where services have deteriorated. Resources can then be allocated to improve services in these areas as indicated in red in Table 4. Although the areas indicated as unfortunate are small in terms of percentage areas they are mostly highly populated. Owing to provincial and sub-place boundary changes between 2001 and 2011 some areas have only FI information for either 2001 or 2011. The percentage of areas shown is based on the area of the province as indicated by Census 2011 spatial data that was published together with the Census 2011 data.

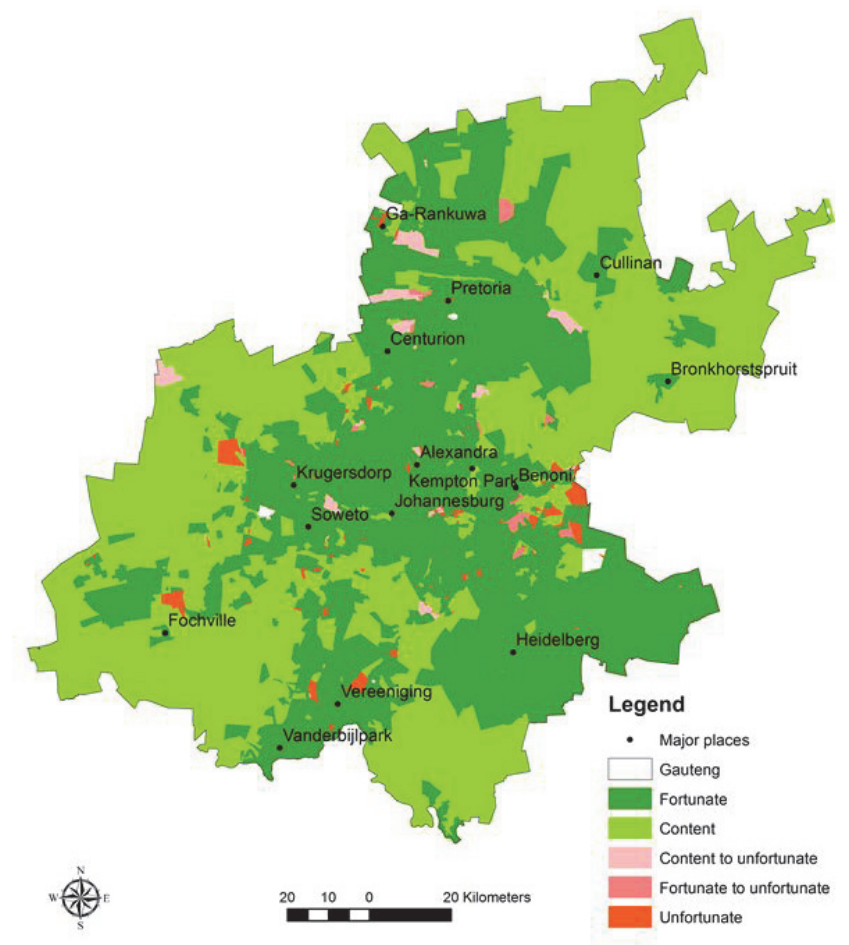

Figure 4. Change in fortunes for Gauteng 


\begin{tabular}{|l|l|}
\hline FI Class & Percentage of area \\
\hline Fortunate (no change) & 24.04 \\
\hline Fortunate 2001 only & 0.31 \\
\hline Fortunate 2011 only & 2.47 \\
\hline Content to fortunate & 17.52 \\
\hline Unfortunate to fortunate & 2.04 \\
\hline Content (no change) & 37.87 \\
\hline Content 2001 only & 0.58 \\
\hline Content 2011 only & 5.34 \\
\hline Unfortunate to content & 3.85 \\
\hline Fortunate to content & 3.54 \\
\hline Unfortunate (no change) & 0.65 \\
\hline Unfortunate 2001 only & 0.17 \\
\hline Unfortunate 2011 only & 0.24 \\
\hline Content to unfortunate & 0.93 \\
\hline Fortunate to unfortunate & 0.44 \\
\hline
\end{tabular}

Table 4. FI change between 2001 and 2011

\section{Conclusion}

In this study, a methodology was established for the calculation of a FI for Gauteng using the census data for 2001 and 2011. These fortunate indices can be plotted on a map and the status quo of an area with regard to how fortunate the area is can be analysed. The FI is based on a list of services and goods available in the Census 2001 and 2011 survey.

The methodology was evaluated using various statistical methods and has indicated that a combination of items needs to be considered when calculating a FI and that the different indicators should be weighted. This index is flexible, and can be adjusted by changing the cut-off score value. It can also be adjusted with regard to gender and age in order to see if these categories show different trends than the overall level of fortune.

Future research regarding this methodology will be to determine the indicators that should be included in the FI. More respondents need to take part in the survey to establish the general rules to be used when calculating the FI. If new variables are included the FI can be refined. However, if new variables are included in the FI it will not be comparable with past FIs. Furthermore, the FI needs to be expanded to the remaining 8 provinces of South Africa. An additional application of the FI results will be to compare it in areas where service delivery protests occur.

The FI makes it possible to visually indicate if government are providing in the needs of the communities. Since the FI combines a number of items from the Census survey it also provides an innovative way of summarising and analysing census data instead of looking at each indicator individually.

\section{References}

Alesina, A., di Tella, R. and MacCulloch, R. (2004). Inequality and happiness: are Europeans and Americans different? Journal of Public Economics. Vol. 88, 2009-2042.

Anand, S. and Sen, A. (2000). The Income Component of the Human Development Index. Journal of Human Development. Vol. 1(1), 83-106

Barrera-Roldan, A. and Saldivar-Valdes, A. (2002). Proposal and application of a Sustainable Development Index. Ecological Indicators Vol. 2, 251-256

Booysen, S. (2014). Political Analyst. Communication by e-mail, 14 August 2014.

Borrero, S., Escobar, A.B., Cortés, A.M. and Maya, L.S. (2013). Poor and distressed, but happy: situational and cultural moderators of the relationship between wealth and happiness. Estudios Gerenciales. Vol. 29, 2-11 
Brereton, F., Clinch, J.P. and Ferreira, S. (2008). Happiness, geography and the environment. Ecological Economics. Vol. 65, 386-396

Carporale, G.M., Georgellis, Y., Tsitsianis, N. and Yin, Y.P. (2009). Income and happiness across Europe: Do reference values matter? Journal of Economic Psycology. Vol. 30, 42-51

CBS, C. (2005). Operations of Gross National Happiness. Royal Government of Bhutan: United Nations Development Programme.

CBS, C. f. (2012). The Sabina-Alkire Method. United Nations Development.

Clark, A., \& D'Angelo, E. (2009). Upward Social Mobility, Well-being and Political Preferences: Evidence from the BHPS.

De Bruin, S. (2013). Developing a Fortunate Index. Unpublished BSc (Hons) Geoinformatics research project report. Department of Geography, Geoinformatics and Meteorology, University of Pretoria, South Africa.

Di Tella, R. and MacCulloch, R. (2008). Gross national happiness as an answer to the Easterlin Paradox? Journal of Development Economics. Vol. 86, 22-42

Easterlin, R.A. (1995). Will raising the incomes of all increase the happiness of all? Journal of Economic Behavior and Organisation Vol. 27, 35-47

Erasmus, J. C., (2004). A development index for the city of Tshwane. Report prepared for the Integrated Policy Research Unit, Human Sciences Research Council Publishers, Prefstoria.

Flango, F.E., Sherbenou, E.L., (2006). Poverty, urbanization, and crime, Criminology, Vol 14 Issue 3, 331.

Heeks, R. (2009). Information Technology and Gross National Happiness: Connecting digital technologies and communications of the ACM, Vol. 55, No 4.

Hicks, D.A. (1997). The Inequality-Adjusted Human Development Index: A Constructive Proposal. World Development. Vol. 25(8), 1283-1298

Kugaso, T. (2008). Japan's Development: what economic growth, human development and subjective well-being measures tell us about. Retrieved March 2013, from http://www.econ.tu.ac.th/doc/article/fulltext/188.pdf

McGillivray, M. (1991) The Human Development Index: Yet Another Redundant Composite Development Indicator? World Development. Vol. 19(10), 1461-1468

Menon, A. (2013, October 2).

Noorbakhsh, F. (1998). The Human Development Index: Some Technical Issues and Alternative Indices. Journal of International Development. Vol. 10, 589-605

NPC. (2014) National Planning Commission, Poverty and inequality.

http://www.npconline.co.za/pebble.asp?relid=123

QoL. (2011). Online Survey Viewer. Retrieved March 2013, from Quality of Life Survey Viewer: Quality of Life Survey Viewer

Rojas, M. (2007). Heterogeneity in the relationship between income and happiness: A conceptual-referent-. Journal of Economic Psyhology, Vol. 28, Issue 1, 1-14.

Simpson, J.A. and Weiner, E.S.C. (1989). The Oxford English Dictionary (2 ${ }^{\text {nd }}$ Edition) Volume VI Follow Haswed. Clarendon Press, Oxford.

StatsSA. (2001). Statistics South Africa. Retrieved January 2012, from Statistics South Africa Census 2001: http://www.statssa.gov.za/census01/html/default.asp

StatsSA. 2014 Poverty Trends in South Africa. An examination of absolute poverty between 2006 and 2011. Beta2.statssa.gov.za/publications/report-03-10-06/report-03-10-06March2014.pdf Retrieved September 2014.

Tongco, C.T. (2007). Purposive Sampling as a Tool for Informant Selection. Ethnobotany Research and Applications 5: 147-158

Ura, K., Alkire, S., Zangmo, T., \& Wangdi, K. (2012). A Short Guide to Gross National Happiness Index. Retrieved February 2013, from Gross National Happiness: http://www.grossnationalhappiness.com/wpcontent/uploads/2012/04/Short-GNH-Index-edited.pdf

YourDictionary. (2013). Retrieved November 1, 2013, from YourDictionary: http://www.yourdictionary.com/fortunate 